\title{
THE EFFECT OF TREATMENT WITH MELATONIN UPON THE ULTRASTRUCTURE OF THE MOUSE PINEAL GLAND: A QUANTITATIVE STUDY
}

\author{
REDINS, G. M., REDINS, C. A. and NOVAES, J. C. \\ Departamento de Morfologia, Centro Biomédico, Universidade Federal do Espírito Santo, CEP 29040-090, \\ Vitória, ES, Brazil \\ Correspondence to: Dr. Carlos Alberto Redins, Rua Cyro Lima, 45, Enseada do Suá, CEP 29050-230, Vitória, ES, \\ Brazil, e-mail: redins@npd.ufes.br \\ Received August 7, 2000 - Accepted October 19, 2000 - Distributed November 30, 2001
}

(With 2 figures)

\begin{abstract}
In order to evaluate melatonin implication in the regulating of its own secretory process by pinealocytes, we used morphometric techniques for transmission electron microscopy. In mice treated with $100 \mathrm{mg}$ of melatonin (N-acetyl-5-methoxy-tryptamine) by daily subcutaneous injection, we observed a decrease in number and volumetric density of lysosomes. Our results showed that melatonin influences the secretory activity of pinealocytes and participates in a complex secretory regulating mechanism.
\end{abstract}

Key words: pineal gland, melatonin, ultrastructure.

\section{RESUMO}

\section{Efeito do tratamento com melatonina sobre a ultra-estrutura da glândula pineal do} camundongo: estudo quantitativo

A fim de avaliar a implicação da melatonina no controle de sua própria secreção pelos pinealócitos, utilizamos técnicas morfométricas aplicadas à microscopia eletrônica de transmissão. Em camundongos tratados com doses subcutâneas diárias de $100 \mathrm{mg}$ de melatonina (5-metoxi-N-acetil-triptamina) observamos uma diminuição do número e da densidade volumétrica dos lisosomos nos pinealócitos. Esses resultados mostram que a melatonina atua sobre a própria glândula pineal, participando de um complexo mecanismo regulador da secreção nos pinealócitos.

Palavras-chave: glândula pineal, melatonina, ultra-estrutura.

\section{INTRODUCTION}

The synthesis of melatonin (N-acetyl-5-methoxy-tryptamine) takes place in several tissues, especially in the pineal gland and retina, where one can observe that its synthesis is rhythmic (Cassone \& Natesan, 1997). The serotonin N-acetyltransferase (NAT), an enzyme that is necessary to produce melatonin, exhibits a daily rhythm with higher nocturnal activity, over a hundred times, when compared with its diurnal activity (Illnerová \& Vanecek, 1986). Although we do not know the precise sites of interaction between melatonin and the neuroendocrine system, its activity involves the hypothalamus, hypophysis, gonads, and the pineal gland itself (Reiter, 1995). In pinealocytes, the secretory activity of melatonin involves the endoplasmic reticulum, Golgi apparatus, lysosomes, and dense-core vesicles, which may be considered as morphological indicators of secretory activity of the pineal gland (Reiter, 1981). Melatonin secretion is regulated by photoperiod alterations that reach the pineal gland through polysynaptic pathways which leave the retinohy- 
pothalamic tract through the suprachiasmatic nucleus $(\mathrm{SCN})$ and superior cervical ganglion, which are responsable for adrenergic innervation of the gland (Arendt, 1998). Melatonin synthesis is regulated by pinealocytic $\beta$-adrenergic receptors, cellular mechanisms which involve cyclic nucleotides, prostaglandins, inositol trisphosphate, and $\mathrm{Ca}^{2+}$ (Reiter, 1986). The structure and secretory activity of pinealocytes can also be altered by several hormones like estrogens, testosterone, progesterone, follicle-stimulating hormone (FSH), luteinizing hormone (LH), and prolactine (revision in Cardinali, 1984). These hormones may act directly upon pinealocytes or alter the sympathetic innervation of the gland, resulting in decreased nerve impulses. The major evidence for direct hormonal activity upon the pineal gland is the demonstration of hormone-receptors in subcellular fractions of the organ. Thus, in the pineal gland of mammals, a lot of receptors have been emonstrated for estrogens, testosterone, progesterone, rolactine, prostaglandins (Cardinali, 1984), and melatonin (Vacas \& Cardinali, 1980). In the pineal gland of rats treated with melatonin, Freire \& Cardinali (1975) reported an increase in the activity of NAT. Likewise, the same increased activity was observed for hydroxyindole-O-methyl-transferase (HIOMT) by Freire \& Cardinali (1975) and Trentini et al. (1982) in these animals. In pineal glands of rats, treated with melatonin, Freire \& Cardinali (1975) also reported morphological alterations of pinealocytes with an increase in the number of ribosomes, microtubules, Golgi cisternae, and annulate lamellae, which suggested increased activity of this organ.

In this research we used morphometric parameters to quantify the dense-core vesicles, lysosomes, Golgi apparatus and lipid droplets of pinealocytes, in order to evaluate the effects of exogenous melatonin upon the secretory activity of the pineal gland in mice.

\section{MATERIAL AND METHODS}

Fifteen male adult Swiss outbred albino mice eight weeks old and separated into three groups of five animals each, were included in the present study. In the experimental group, at $10 \mathrm{~h}$ the animals received daily subcutaneous melatonin (Sigma) injections of $100 \mathrm{mg}$ in $0.1 \mathrm{ml}$ of vehicle (5\% alcoholic saline) during 22 consecutive days, according to Lang et al. (1983, 1984). The shamcontrol group animals received at $10 \mathrm{~h}$ a.m. daily s.c. vehicle injections of $0.1 \mathrm{ml}$ during 22 consecutive days. The control group animals received no treatment. During the whole experiment the animals were housed in separate groups, under normal laboratory conditions with respect to natural light (12:12 h light-dark cycle), with food and water ad libitum. Twenty-four hours after the last injection, the animals were killed by cervical decapitation under ether anesthesia; the pineal glands were immediately removed and rapidly flooded with Karnovsky's fixative solution $(0.8 \%$ paraformaldehyde and $1.5 \%$ glutaraldehyde in 0.2 $\mathrm{M}$ cacodylate buffer at $\mathrm{pH}$ 7.4). The organs were post-fixed in $1 \%$ osmium tetroxide solution for $1 \mathrm{~h}$, buffered at $\mathrm{pH} 7.2$ with Na-cacodylate $(0.1$ $\mathrm{M})$, subsequently dehydrated in an ascending sequence of ethanol and acetone, and embedded in Epon 812. Thin sections, prepared with a diamond knife and a Reichert Jung Super Nova microtome, were stained with uranyl acetate and lead citrate (Reynolds, 1963). These sections were examined and photographed in a Zeiss EM 10 electron microscope from the Center for Electron Microscopy - Institute of Biological Sciences UFMG.

For quantitative estimation, ten $18 \times 24 \mathrm{~cm}$ micrographs, at a final magnification of X12,500, were taken from each mouse using systematic random sampling. Each $\mathrm{cm}^{2}$ on the micrograph represented $0.64 \mu \mathrm{m}^{2}$ of pineal tissue. From each animal a total area of $2,764.80 \mu \mathrm{m}^{2}$ of pineal tissue was measured and the dense-core vesicles and lysosomes present in the micrographs were counted and the data expressed as the number of these structures per $100 \mu \mathrm{m}^{2}$ of area of pinealocytic cytoplasm.

In order to determine the volumetric density of pineal components we counted incident points on dense-core vesicles, lysosomes, Golgi apparatus, and lipid droplets, using a net-like plastic transparency which contained 450 points in a symmetrical arrangement. The resulting data were expressed by mean of percentages occupied by structures in the cytoplasm of pinealocytes, with the respective standard error of the mean. For all groups of mice, the means were statistically compared using the Student $\mathrm{s} t$-test and the differences between the means were considered to be significant for $\mathrm{p}<0.05$. 


\section{RESULTS}

The pinealocytes of mice have a cell outline which is difficult to make out in histological sections. The cells show frequent complex interdigitations with other pinealocytes and its nuclei are round to ovoid and usually contain indentations and prominent nucleoli (Fig. 1). The perikaryon and cytoplasmic processes contain both rough and smooth endoplasmic reticulum, numerous mitochondria, Golgi apparatus, lysosomes, lipid droplets, and small secretory vesicles, some of which with electron-dense cores (granulate vesicles or dense-core vesicles) (Fig. 2). The quantitative data are assembled in Table 1. In the group treated with melatonin we observed a decrease in the number and volumetric density of dense-core vesicles and an increase in the number and volumetric fractions of lipid droplets and Golgi apparatus. On the other hand, there was not any statistically significant difference when we compared the control and the sham-control groups.

\section{DISCUSSION}

The dense-core vesicles are particularly frequent in pinealocytes of mice and their enclosed flocculent material, which is believed to be proteinaceous in nature, and may contain active peptides, serotonin, melatonin and other pineal indoles (Vollrath, 1984). In rat pinealocytes, Karasek et al. (1990) reported an increase in the number of dense-core vesicles, during the day when the levels of serum melatonin were usually depressed. Likewise, melatonin titers in the blood were often augmented, during the night, while the number of dense-core vesicles diminished. These data suggest that melatonin probably is stored in dense-core vesicles. The proteinaceous secretory content of granulate vesicles could be related to the transport of pineal hormones (Collin et al., 1986).

The number of dense-core vesicles in pinealocytes shows a circadian rhythm and varies according to reproductive activity (Novaes et al., 1998; Redins \& Novaes, 1995; Redins et al., 1997, 1999) and the age of the animals (Redins \& Novaes, 1999).

In the rat, hamster, and mouse pinealocytes, Haldar-Misra \& Pévet (1983a, b) reported, in vitro, that melatonin, together with norepinephrine, provokes a decrease in the number of dense-core vesicles. In the absence of norepinephrine, the same authors reported that melatonin induces the formation of dense-core vesicles in rat pinealocytes.

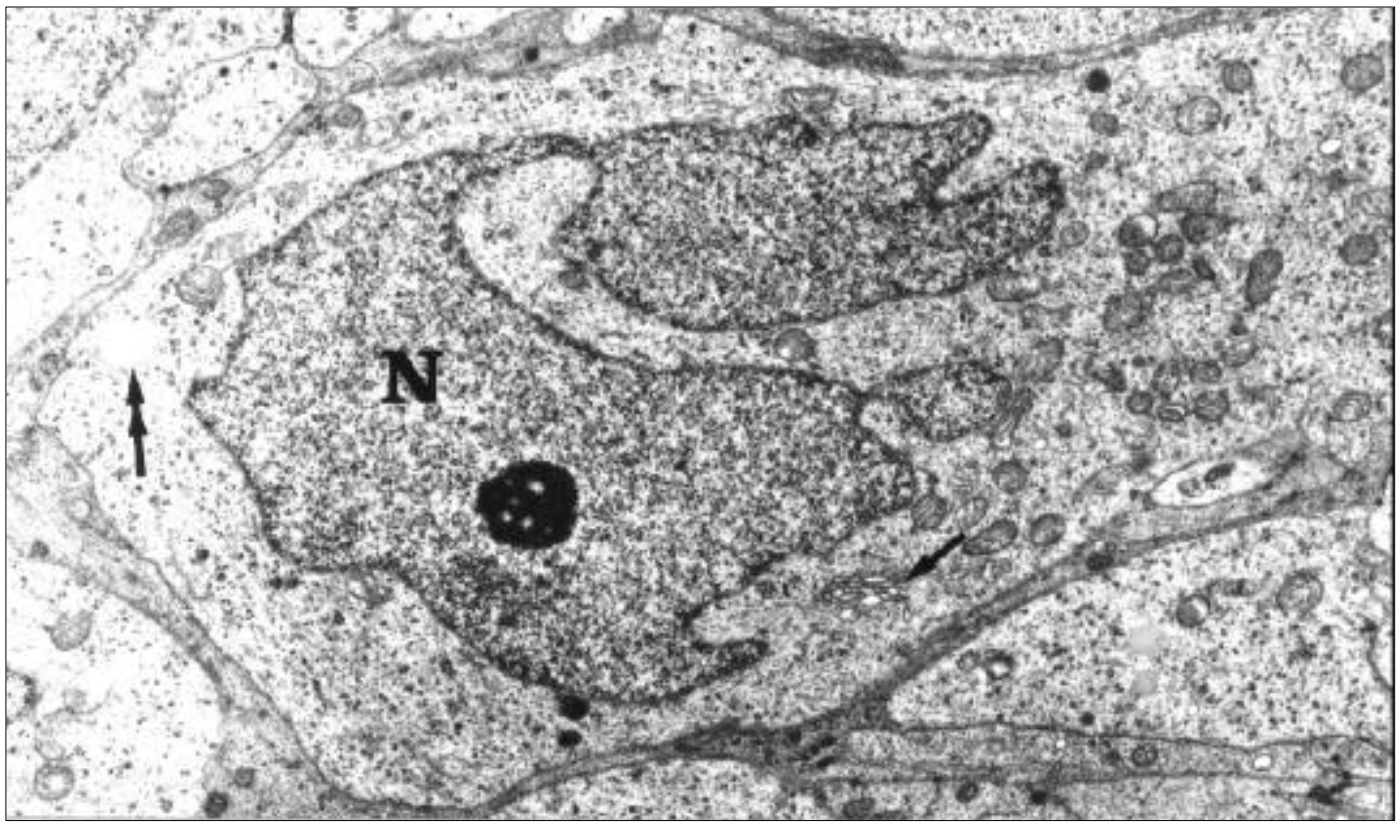

Fig. 1 - Pinealocyte of mouse, treated with melatonin, showing an indented nucleus $(\mathrm{N})$ with a prominent nucleolus. Single arrow $=$ Golgi apparatus; double arrow $=$ lipid droplet. $\mathrm{X} 8,000$. 


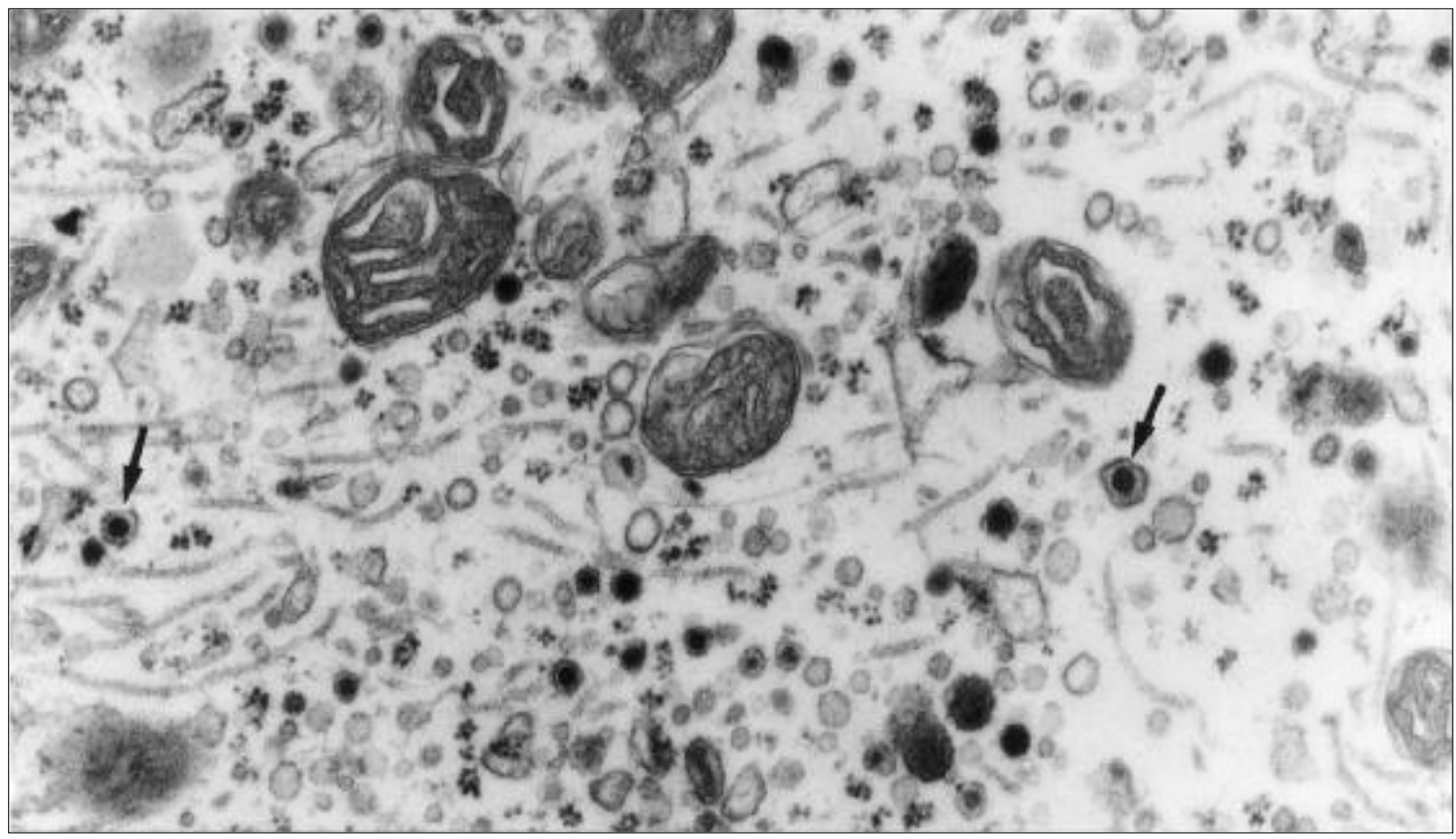

Fig. 2 - Portion of the cytoplasm of mouse pinealocyte, treated with melatonin, showing dense-core vesicles (arrows). X37,000.

TABLE 1

Number of dense-core vesicles and lysosomes and volumetric fraction of dense-core vesicles, lysosomes, lipid droplets, and Golgi apparatus of male mice pinealocytes from control group, sham-control group, and the group treated with melatonin. Mean \pm SEM.

\begin{tabular}{|l|c|c|c|}
\hline \multicolumn{1}{|c|}{ Analyzed parameters } & Control group & Sham-control group & Melatonin group \\
\hline $\begin{array}{l}\text { Number of dense-core vesicles } \\
\text { per } 100 \mu \mathrm{m}^{2} \text { of pinealocytic } \\
\text { cytoplasm }\end{array}$ & $16.386 \pm 0.834$ & $17.388 \pm 2.786$ & $9.080 \pm 1.330^{*}$ \\
\hline $\begin{array}{l}\text { Number of lysosomes per } 100 \mu \mathrm{m}^{2} \\
\text { of pinealocytic cytoplasm }\end{array}$ & $2.315 \pm 0.125$ & $2.582 \pm 0.234$ & $3.523 \pm 0.296^{*}$ \\
\hline $\begin{array}{l}\text { Volumetric fraction of dense-core } \\
\text { vesicles (\%) }\end{array}$ & $0.409 \pm 0.037$ & $0.426 \pm 0.012$ & $0.225 \pm 0.019^{* *}$ \\
\hline $\begin{array}{l}\text { Volumetric fraction of lysosomes } \\
(\%)\end{array}$ & $0.269 \pm 0.034$ & $0.263 \pm 0.018$ & $0.579 \pm 0.110^{* * *}$ \\
\hline $\begin{array}{l}\text { Volumetric fraction of lipid } \\
\text { droplets (\%) }\end{array}$ & $1.254 \pm 0.269$ & $1.293 \pm 0.455$ & $1.214 \pm 0.377$ \\
\hline $\begin{array}{l}\text { Volumetric fraction of Golgi } \\
\text { apparatus (\%) }\end{array}$ & $0.256 \pm 0.042$ & $0.201 \pm 0.075$ & $0.401 \pm 0.106$ \\
\hline
\end{tabular}

* $\quad \mathrm{p}<0.01$ in relation to control group and $\mathrm{p}<0.05$ in relation to sham-control group;

$* * \mathrm{p}<0.01$ in relation to control and sham-control groups;

$* * * \mathrm{p}<0.05$ in relation to control and sham-control groups;

$\mathrm{n}=5$.

Our results in vivo show that melatonin provokes a decrease in the number and volumetric fraction of dense-core vesicles, suggesting a possi- ble role in the secretory activity of pinealocytes. According to Freire \& Cardinali (1975) and Trentini et al. (1982), in pineal glands of rats, 
treated with melatonin, this hormone induces the secretory activity of pinealocytes. These data are not in accordance with our results and will be compared to the findings reported by Haldar-Misra \& Pévet (1983a, b) when a lack of norepinephrine occurs.

In mouse pinealocytes, treated with melatonin, the increase in the number and volumetric fraction of lysosomes, concomitant with a decrease of dense-core vesicles, could be related to a possible role of these organelles in controlling the release of the pineal's hormones. A similar feature occurs at the hypothalamo-neuro-hypophyseo axis, where lysosomes are involved in the process of fractioning protein carriers and releasing mechanism of hormones (Castel et al., 1984).

In mice pinealocytes treated with melatonin, even with participation of Golgi apparatus in the mechanism of formation of dense-core vesicles (Karasek, 1986), our results could not show any significant variation in the volumetric fraction of this organelle. Likewise, we could not observe any difference in the volumetric fraction of lipid droplets. Besides, they were particularly frequent in pinealocytic cytoplasm. These lipid inclusions should be considered by some authors as secretory products of pinealocytes or places for storage of secretion (Vollrath, 1981).

In mice pinealocytes treated with melatonin, our results show a quantitative decrease of densecore vesicles and an increase in the number of lysosomes. Such alterations in the secretory process of pinealocytes suggest that melatonin acts upon the pineal gland, and takes part in a complex regulatory mechanism of secretion in these cells. The presence of melatonin receptors in the pineal organ (Vacas \& Cardinali, 1980) and the results in vitro of Haldar-Misra \& Pévet (1983a, b) indicate that melatonin may act selectively upon the secretory mechanism of pinealocytes.

Acknowledgments - We thank the Center for Electron Microscopy - Institute of Biological Sciences - UFMG and the $\mathrm{CNPq}$ for financial support.

\section{REFERENCES}

ARENDT, J., 1998, Melatonin and the pineal gland: influence on mammalian seasonal and circadian physiology. Reviews of Reproduction, 3: 13-22.
CARDINALI, D. P., 1984, Neural-hormonal integrative mechanisms in the pineal gland and superior cervical ganglia. In: R. J. Reiter (ed.), Comprehensive Endocrinology: The Pineal Gland. Raven Press, New York, pp. 83-107.

CASSONE, V. M. \& NATESAN, A. K., 1997, Time and time again: the phylogeny of melatonin as a transducer of biological time. J. Biol. Rhythms, 12(6): 489-497.

CASTEL, M., GAINER, H. \& DELLMANN, H. D., 1984, Neuronal secretory systems. Int. Rev. Cytol., 88: 303-459.

COLLIN, J. P., MEISSL, H., VOISON, P., BRISSON, P. \& FALCON, J., 1986, Rhythmic signals of pineal transducers: physiological, biochemical and cytochemical evidence. In: R. J. Reiter \& M. Karasek (eds.), Advances in Pineal Research. John Libbey \& Company Ltd., London, pp. 41-50.

FREIRE, F. \& CARDINALI, D. P., 1975, Effect of melatonin treatment and environmental lighting on the ultrastructural appearance, melatonin synthesis, norepinephrine turnover and microtubule protein content of the rat pineal gland. J. Neural Transm., 37: 237-257.

HALDAR-MISRA, C. \& PÉVET, P., 1983a, The influence of different 5-methoxyindoles on the process of protein/ peptide secretion characterized by the formation of granular vesicles in the mouse pineal gland. An in vivo study. Cell Tissue Res., 230(1): 113-126.

HALDAR-MISRA, C. \& PÉVET, P., 1983b, The influence of melatonin on the process of protein and/or peptide secretion in the pineal gland of rat and hamster. An in vivo study. Cell Tissue Res., 231(1): 73-82.

ILLNEROVÁ, H. \& VANECEK, J., 1986, Effect of light on the $\mathrm{N}$-acetyltransferases rhythm in the rat pineal gland. In: R. J. Reiter \& M. Karasek (eds.), Advances in Pineal Research. John Libbey \& Company Ltd., London, pp. 6976.

KARASEK, M., 1986, Quantitative aspects of the ultrastructure of the mammalian pinealocyte. In: R. J. Reiter \& M. Karasek (eds.), Advances in Pineal Research. John Libbey \& Company Ltd., London, pp. 9-18.

KARASEK, M., STANKOV, B., LUCINI, V., SCAGLIONI, F., ESPOSTI, G., MARIANI, M. \& FRASCHINI, F., 1990, Comparison of the rat pinealocyte ultrastructure with melatonin concentrations during daytime and at night. J. Pineal Res., 9(4): 251-257.

LANG, U., AUBERT, M. L., CONNE, B. S., BRADTKE, J. C. \& SIZONENKO, P. C., 1983, Influence of exogenous melatonin on melatonin secretion and on the neuroendocrine reproductive axis of intact male rats during sexual maturation. Endocrinology, 112: 1578-1584.

LANG, U., RIVEST, R. W., SCHLAEPFER, L. V., BRADTKE, J. C., AUBERT, M. L. \& SIZONENKO, P. C., 1984, Diurnal rhythm of melatonin action on sexual maturation of male rats. Neuroendocrinology, 38: 261268. 
NOVAES, J. C., REDINS, C. A. \& CARVALHO, R. D., 1998, The effects of castration on the dense-core vesicles and lysosomes of pinealocytes in adult mice: a quantitative study. Braz. J. morphol. Sci., 15(1): 3-7.

REDINS, C. A. \& NOVAES, J. C., 1995, Morphology of the pineal organ in some wild rodents. Rev. Brasil. Biol., 56(3): 621-626.

REDINS, C. A. \& NOVAES, J. C., 1999, Ultrastructure of the pineal gland in Akodon arviculoides cursor (Rodentia: Cricetidae): a quantitative study of dense-core vesicles. Braz. J. morphol. Sci., 16(1): 105-111.

REDINS, C. A., NOVAES, J. C., LIMA, M. T. V. \& GOMES, G. E., 1997, Ultrastructural comparison of pineal secretory rudimentary photoreceptor cells in Crypturellus parvirostris (Aves: Tinamiformes) during breeding and resting periods: a quantitative study. Rev. Brasil. Biol., 57(3): 521-529.

REDINS, C. A., NOVAES, J. C. \& TORRES, K. B., 1999, The effects of testosterone on the mice pinealocytes: a quantitative study. Tissue \& Cell, 31(1): 233-239.

REITER, R. J., 1981, The mammalian pineal gland: structure and function. Am. J. Anat., 162: 281-313.

REITER, R. J., 1986, Pineal melatonin production: photoperiodic and hormonal influences. In: R. J. Reiter \& M. Karasek (eds.), Advances in Pineal Research, 1. John Libbey \& Company Ltd., London, pp. 89-98.
REITER, R. J., 1995, Functional pleiotropy of the neurohormone melatonin: antioxidant protection and neuroendocrine regulation. Frontiers in Neuroendocrinology, 16 383-415.

REYNOLDS, E. S., 1963, The use of lead citrate at high $\mathrm{pH}$ as an electron opaque stain in electron microscopy. $J$. Cell Biol., 17: 208-212.

TRENTINI, G. P., DE GAETANI, C. F., CRISCUOLO, M., BALEMANS, M. \& SMITH, I., 1982, The effect of melatonin and other indole derivatives in maintaining ovulation in rats kept in continuous light and the influence of these indoles on HIOMT activity in the pineal gland. J. Neural Transm., 53: 305-314.

VACAS, M. I. \& CARDINALI, D. P., 1980, Binding sites for melatonin in bovine pineal gland. Horm. Res., 13: 121131.

VOLLRATH, L., 1981, The Pineal Organ. Springer-Verlag, Berlin, 665p.

VOLLRATH, L., 1984, Functional anatomy of the human pineal gland. In: R. J. Reiter (ed.), Comprehensive Endocrinology: The Pineal Gland. Raven Press, New York, pp. 285-322. 